\title{
DIFFICULTIES WITH EXISTING FISH PASSES AND THEIR RENOVATION. THE POOL FISH PASS ON DŁUBNIA RIVER IN KRAKOW
}

\author{
Artur Radecki-Pawlik ${ }^{1}$, Răzvan Voicu², Karol Plesiński ${ }^{3 凶}, G^{\natural}$ rzegorz Gajda ${ }^{3}$, \\ Bartosz Radecki-Pawlik ${ }^{1}$, Liliana Voicu², Leszek Książek ${ }^{3}$ \\ ${ }^{1}$ Faculty of Civil Engineering, Cracow University of Technology, ul. Warszawska 24, 31-155 Kraków \\ 2 National Institute of Hydrology and Water Management, Romania \\ 3 Faculty of Environmental Engineering and Land Surveying, University of Agriculture in Krakow, Al. Mickiewicza 24/28, \\ 30-059 Kraków
}

\begin{abstract}
The aim of study

The aim of study was to determine, how the pool fish pass located on the Dłubnia River operates and to formulate recommendations, due to which it will work effectively and will not be an obstacle for migrating fish.

\section{Materials and methods}

Field work. Identification of elements of fish pass that may restrict fish migration on the grounds of standard geometrical dimensions. An attempt to design its repair.
\end{abstract}

\section{Results and conclusions}

The fish pass does not operate effectively. The paper presents recommendations for its improvement.

Keywords: fish pass, weir, renovation, fish pass effectiveness

\section{INTRODUCTION}

Majority of damming constructions that entirely intersect river beds is causing significant changes in biological life conditions. In particular, they restrict fish migration, which means that fish try to leave these sections of watercourses, moving to those that provide normal living conditions. Therefore, for each hydrological construction, where there is a difference in water levels, special structures should allow fish to pass from upper to lower levels and reversely, while considering particular features of fish species. These are so-called fish passes or ladders (Jarocki, 1966; Kałuża and Hammerling, 2015; Mokwa and Tymiński, 2018; Radecki-Pawlik et al., 2017; Skatula, 1964; Wyrębek, 2013). Structurally, these are usually rectangular beds with a slope connecting an upper station with a lower. Fish passes are built either as beds placed in pillars or abutments of hydrological constructions or in a form of separate gutters directly connecting upper and lower water levels. Material used for their construction is: reinforced concrete, concrete, wood or stones. Fish passes can be divided into two types: uniformly inclined and stepped, which include channel and ladder types.

Because water flow rate in fish passes must be within certain limits, at which fish can still move freely, it should - depending on fish species - be adopted in a range of $1.5 \div 2.0 \mathrm{~m} \cdot \mathrm{s}^{-1}$, allowing an exceptional speed of $3.0 \mathrm{~m} \cdot \mathrm{s}^{-1}$ for salmon (DWA, 2014, Gebler, 1991, Bartnik et al., 2011). Determining flow velocity in this range is also related to water flowing through

凶e-mail: e-mail: kplesinski@ar.krakow.pl 
passageway of a fish pass. Because the volume of water flowing from an upper to a lower level can sometimes be about several hundred litres per second, the design of a fish pass should consider its limiting to the possible minimum. In addition to flow rate, the volume of water flow also depends on a cross-section and mainly on bed width. When travelling upstream for a longer period, fish must be provided with a chance to rest every few meters. For this reason a fish pass contains from a few to a dozen rest pools. In general, a fish pass with bed width not exceeding $2.0 \mathrm{~m}$ and depth to $0.5 \div 1.5 \mathrm{~m}$ should be ensured for large fish, such as salmon.

Inclination of bottom of a transitional bed usually varies within $1: 4$, and in a bed with increased roughness it is even $1: 1.5 \div 1: 1$. With such relatively large slopes of longitudinal beds, velocity reduction is achieved by intersecting a flow gutter with transverse walls. Instead of cutting a gutter through an entire width, these walls could partition a gutter in such a way that fish move through existing slots without much effort. When a flow gutter is completely divided, fish may pass it either above the partitions or through the slots. This kind of fish pass is called stairway for fish, ladder type. Figure 1 shows an example of a pool fish pass. The distance between the end of a compartment and the walls of a bed should not be less than $30 \mathrm{~cm}$. Water depth should be approx. $50 \mathrm{~cm}$. In Table 1 and 2 pools dimensions are presented according to fish species.

To facilitate fish with smooth and easy movement, both in and out of a fish pass and stairway, inlets in the upper level and outlets in the lower level should be at least $50 \mathrm{~cm}$ below water table. Too deep submerging below water table is, however, inadvisable.

Fish passes of this type can be built at water table heights up to $30.0 \mathrm{~m}$. However, in case of high levels of watercourse, longer sections with a small slope should be placed in a channel, where fish could rest after passing a section, where a difference in height of the starting and ending points is about $4.0 \mathrm{~m}$.

Since fish travel only during the day (except for eels), fish passes must be illuminated, preferably with natural light (for protection against poachers they are covered with a tight, light-transmitting screen from above). Fish pass should be situated as close as possible to the current of watercourse, because fish instinctively seek a passage in places, where there is disturbance in water. At the bottom, a layer of sand or gravel can be put in order to create conditions close to natural.

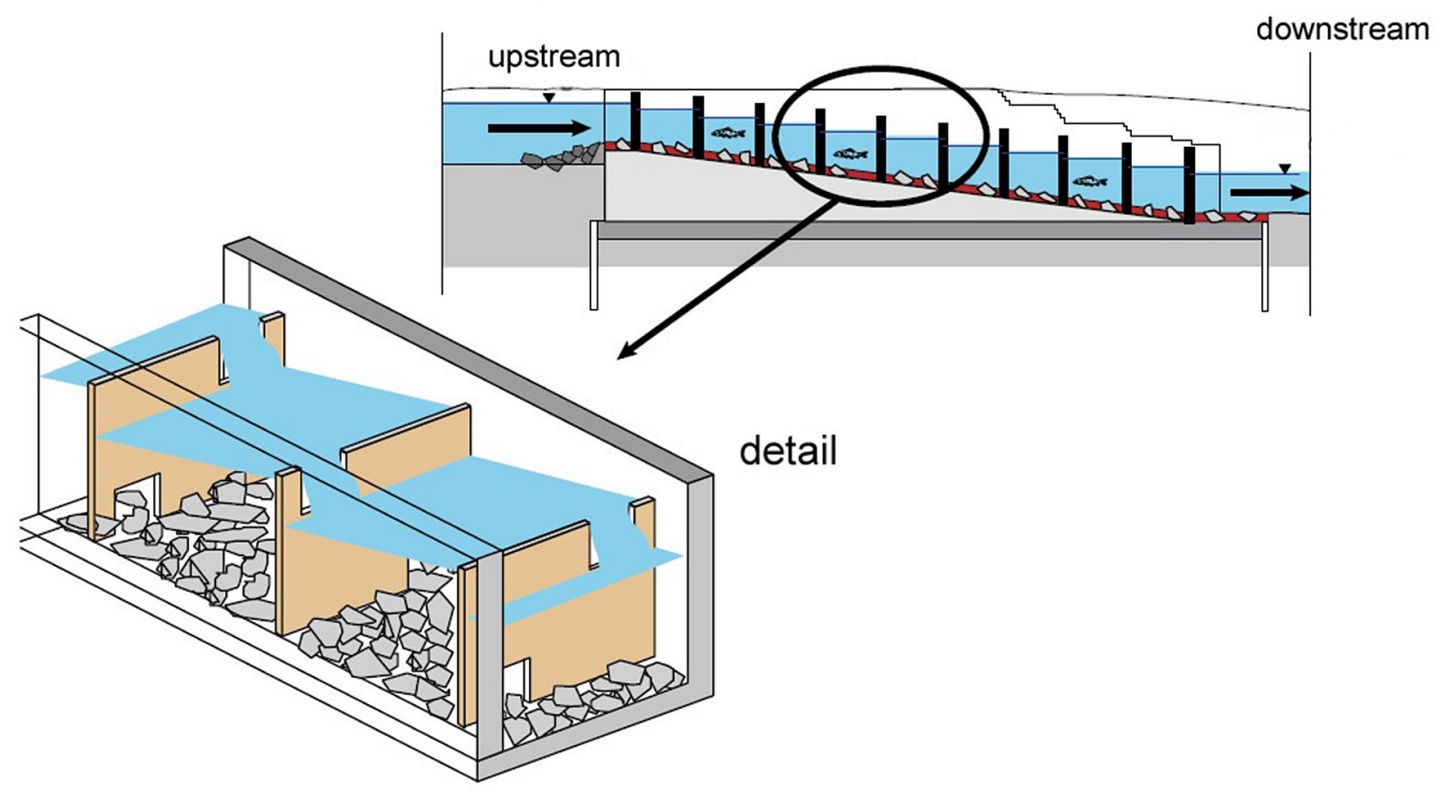

Fig. 1. Scheme of conventional pool fish pass (WWF, 2016; Jens, 1982) 
Table 1. Recommended dimensions for pool passes (WWF 2016)

\begin{tabular}{lccc}
\hline \multicolumn{1}{c}{ Fish species } & $\begin{array}{c}\text { Length } \\
{[\mathbf{m}]}\end{array}$ & $\begin{array}{c}\text { Width } \\
{[\mathbf{m}]}\end{array}$ & $\begin{array}{c}\text { Water depth } \\
{[\mathbf{m}]}\end{array}$ \\
\hline Salmon, sea trout & $2.5-3.0$ & $1.6-2.0$ & $0.8-1.0$ \\
Bream, chub & $1.4-2.0$ & $1.0-1.5$ & $0.6-0.8$ \\
Upper trout zone & $>1.0$ & $>0.8$ & $>0.6$ \\
\hline
\end{tabular}

Table 2. Dimensions of notches and submerged orifices (WWF 2016)

\begin{tabular}{lcccc}
\hline \multirow{2}{*}{ Fish species } & \multicolumn{2}{c}{$\begin{array}{c}\text { Notches } \\
{[\mathrm{cm}]}\end{array}$} & \multicolumn{2}{c}{$\begin{array}{c}\text { Submerged orifices } \\
{[\mathrm{cm}]}\end{array}$} \\
\cline { 2 - 5 } & Height & Width & Height & Width \\
\hline Salmon, sea trout & 30 & 30 & $40-50$ & $30-40$ \\
Bream, chub & 25 & 25 & $25-35$ & $25-35$ \\
Upper trout zone & 20 & 20 & 20 & 20 \\
\hline
\end{tabular}

An important element that enables smooth operating of a fish pass is the location of an outlet, i.e. an entrance, which fish take travelling from the bottom to the upper station. Inlets and outlets should be mounted at least $0.5 \mathrm{~m}$ from water surface (fish pass is to operate during the highest and lowest water levels). Fig. 2 shows several location variants of an outlet of a fish pass. The best solution is when fish moving against the current can take a straight path, and the direction of a river coincides with the direction of an attracting stream (Bartnik et al., 2010).

Aim of the study is to assess the technical condition of a pool fish pass in a weir pillar on the Dłubnia River in Cracow. Research included field work, assessment of technical conditions in terms of possibility of fish migration through the aforementioned fish pass and the elaboration of recommendations for improving that will restore functionality of the structure.
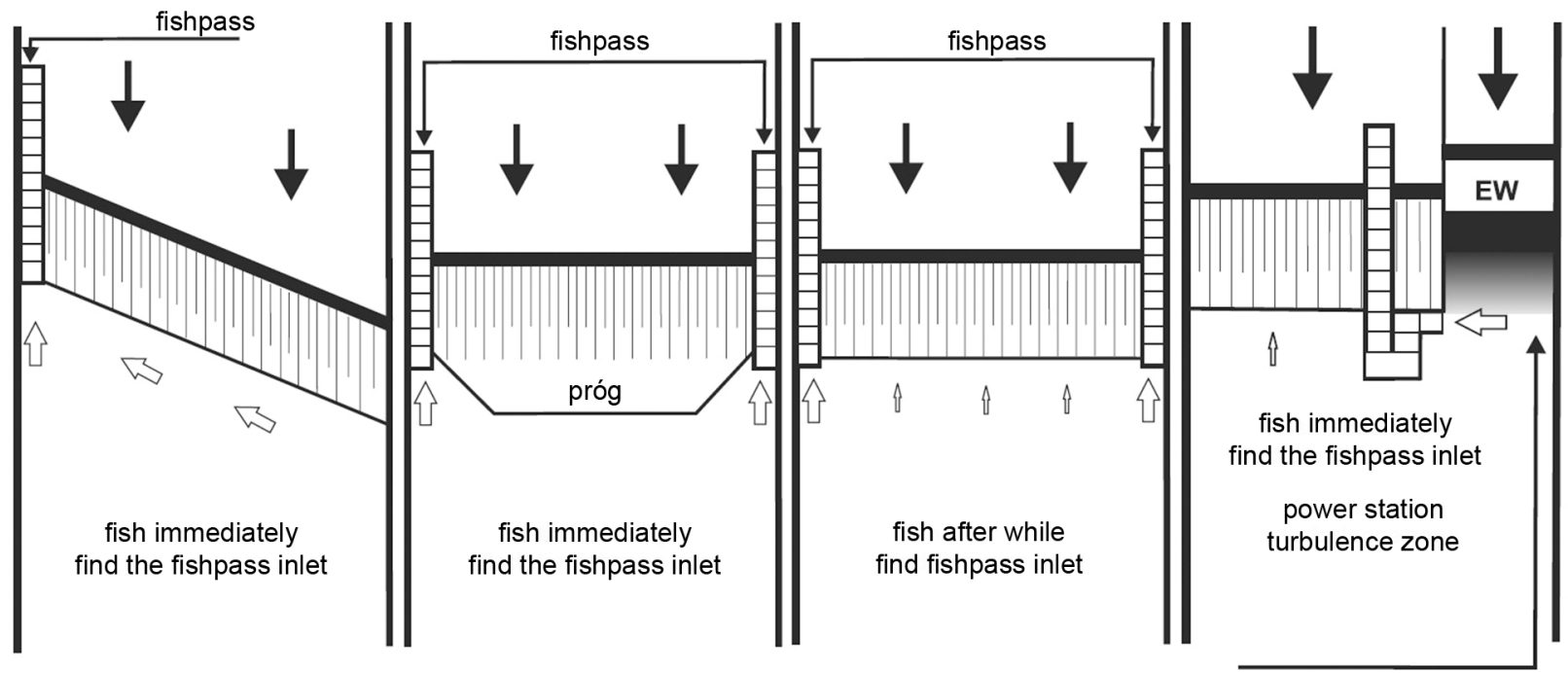

Fig. 2. Location of a fish pass outlet in relation to watercourse (Bojarski et al., 2005)

\section{INTERNATIONAL AND POLISH ACTIVITIES FOR RECONSTRUCTION OF FISH MIGRATION}

The international symposium in Koblenz in 1992 focused on the theme of "Long-distance migrating fish (salmonidae) in dammed rivers" should be considered as the first step towards restoration of fish migration routes. In the conference participated scientists looking for the best solutions for the "Rhine Action Program" developed by the International Commission for the Protection of the Rhine, composed of ministers of environment from the six Rhenish provinces (Länder). Barrages on the Rhine pose as unbeatable obstacles for fish. For this reason, complex fish ladders were be- 
ing built - cascades up to 10 meters high. However, despite repeated modernizations, most fish have trouble not only finding an outlet of a fish pass, but also crossing it. Realisation of this program has begun with constructing developed fish passes at the lowest barrages of the Rhine: Iffezheim and Gambsheim. Even well-functioning fish passes existing at reservoirs not always guarantee smooth traffic along the river, because reservoirs, due to their size and impact on environment, can become an obstacle on fish journey up the river. This problem occurred at the Vohburg barrage on the Danube. The situation can be improved by developing coastal structures: bights, zones of slowed flow. A more expensive but effective solution in a form of a mix of fish pass and circular channel with short riffles and deeper pools was used on the Vohburg barrage. The 6.5-kilometer-long channel allows to bypass the reservoir and direct fish to the river, where flow conditions are similar to natural. Shape and structure of the channel are similar to natural: there are mild and very steep slopes, precipitous banks, enlargements and narrowings, islands and zones of slow water flow with reed flora. A similar solution was used at the Kinsau barrage at the Lech river. There, a circular channel running was built along a side dam.

An example of a country leading a well-thought-out pro-ecological policy in the field of river revitalization (including the construction of fish passes) is France. It employed research and vast experiments conducted by the USA and Canada in the 1940s. A number of studies and initiatives have been undertaken since the 1970s, and in 1984 a special legal act was introduced to rebuild the salmon population. The program of reinstituting the salmon population in the Loara anticipated, among others, such unusual activities as the demolition of the Saint-Etienne-du-Vigan dam located on the left tributary of the Loire - Allier. About 100 thousand salmons entered the Loire at the end of the last century for spawning, and in 1997 their number was estimated only 389 . The dam was blown up on June 24, 1998. Removal of another is also planned: the Maisons-Rouges dam on the Vienne River, a tributary of the Loire. The aim of this project is to reach a salmon population of 6,000 within ten years. Similar measures are planned in the United States regarding the Edward barrage on the Kennebek River (Zubek, 1998). In the years 19821994 about 400 fish passes were built in France. The company "Electrification of France" is, among others, the driving force of these operations.

In Romania, which is one of the youngest member states of the European Union, the Water Framework Directive (Directive 60/2000/EU) was also introduced. It obliges member states to restore good ecological conditions in their rivers. Also in Romania, a number of related projects were aimed at facilitating water flow in rivers and streams for fish migrating upstream. Projects of unclogging the existing barriers in a form of either dams with inactive fish passes or water barrages without any systems supporting migration of fish were implemented on the rivers: Ialomiţa, Somes Mic and Micheşul, Someşul and Hârtibaciu in the Romanian Carpathians. As a result, bypasses for fish were designed, riffles with increased roughness and fish ladders (Voicu and Bretcan, 2014; Voicu et al., 2015; Voicu and Dominguez, 2016; Voicu and Miles, 2016; Voicu and Baki, 2017).

In Poland, the selection of appropriate technical solutions and their implementation is mainly influenced by economic reasons. The desire to reduce costs of hydrotechnical constructions often meant failure in building fish passes. This conflict of interests between environmental protection and investors has been formally and legally solved by the Regulation of the Minister of Agriculture and Natural Resources of December 20, 1996 on technical conditions that should be met by water management facilities. It entered into force on April 4, 1997. Pursuant to the regulation, "technical structures intersecting a river should be equipped with devices ensuring free passage of fish through an obstacle" (Rozporządzenie...). It is therefore an obligatory requirement to build fish passes at every damming structure, whereas previously this requirement pertained only to a small number of cases, where "aquifers constitute a hindrance to fish migration and when there is a proven need to maintain them." Practically, the previous regulation allowed skipping constructing of fish passes. One of the consequences of this provision was also a failure to attach importance to proper functioning and maintenance of built-in fish passes. Utilizing older barrages with fish passes according to intention and maintaining their full efficiency is not common.

In Poland, there is an increasing number of environmental plans for rivers or even entire river basins. Two programs can serve as examples: "Construction of 
a blue ecological corridor along the Rega River valley and its tributaries" (Witkowska et al., 2013a, 2013b), "Restoration of ecological continuity and implementation of measures to improve the functioning of a free migration corridor of the Biała Tarnowska River" (https://biala-tarnowska.org/) and Wisłoka (Bartnik et al., 2015). The first project was implemented in 20122017 on the Reda River and its tributaries by the West Pomeranian Board of Amelioration and Water Facilities in Szczecin with the participation of the Regional Directorate for Environmental Protection in Szczecin. As part of the project, 23 structures were constructed to allow fish to migrate upstream (these are mainly technical fish passes, circular channels and riffles with increased roughness), and $12.000 \mathrm{~m}^{2}$ spawning sites were created. In addition, devices to monitor their migrations have been installed on some of the facilities used for fish migration, which provides with an ongoing analysis of efficiency of a given fish pass and control of its operation. On the other hand, on water barrages consisting of hydroelectric power plants and entrances to fish passes that have been designed and constructed outside turbulence zone or where an attractor current is too weak for fish to sense it and find the entrance to a structure, electrical-electronic barriers have been installed. It is supposed to protect fish from dangerous operation of water turbines in power plants, where in case of unwanted inflow of fish, they may get injured or even killed. However, barriers in an area of inlet to a fish pass are used to prevent fish from bypassing the entrance to a fish pass. An additional task carried out within the project was afforestation of riverside areas, which was supposed to increase shading of riverbeds and diversification of thermal conditions in water (Witkowska et al., 2013a, 2013b).

The second of the mentioned projects is being run in the Carpathian region on the Biała Tarnowska and Wisłoka rivers, the beneficiary of which is the Polish National Water Management Authority, and the Regional Water Management Board in Cracow. Existing hydrotechnical constructions, like migration barriers for fish, will be improved as part of this project. Depending on the local situation and conditions of existing facilities, a restoration task will be implemented as a result of a reconstruction of existing objects into riffles with increased roughness, mainly cascade type and so-called "honeycomb" (Plesiński and Radecki-Paw- lik, 2018; Tymiński et al., 2016), making stiffeners from broken boulders, lowering transfers on barrages inhibiting migration and dismantling buildings that cannot be restored to patency through reconstruction (https://biala-tarnowska.com). Both described above projects, implemented on mountain and lowland rivers, show a growing environmental awareness among engineers and contractors from the hydrotechnical industry and a new quality of created and constructed water structures in river channels.

\section{DESCRIPTION OF THE STUDIED STRUCTURE}

The fish pass discussed in this work is part of a mobile weir, located on the Dłubnia River in Cracow, operated by the Water Department of Tadeusz Sendzimir Steelworks (BSiPH, 1995; Radecki-Pawlik et al., 2015). The Dłubnia River is a left tributary of the Vistula River. The weir was constructed according to the General Project for regulation of the Dłubnia River. Existing wooden weir in Bieńczyce has been removed. A new weir has been mounted upstream the old. Table 3 shows a probability of occurrence of high waters on the Dłubnia River on the Zesławice water gauge. According to Michalec (2013), conducted by the Polish Angling Association in 2007 research fishing indicates the occurrence of the following fish species in the Dłubnia River: brown trout, grayling, roach, silver crucian, alpine bullhead and perch.

Table 3. Maximum flows with a determined probability of overflowing on the Dłubnia River on the Zesławice water gauge - in an area of the existing fish pass

\begin{tabular}{lcc}
\hline & przepływ Q $\left[\mathrm{m}^{3} \cdot \mathrm{s}^{-1}\right]$ & stan wody $\mathrm{H}[\mathrm{cm}]$ \\
\hline $\mathrm{Q}_{1 \%}$ & 104 & 477 \\
\hline $\mathrm{Q}_{0,5 \%}$ & 119 & 491 \\
\hline $\mathrm{Q}_{0,2 \%}$ & 138 & 510 \\
\hline
\end{tabular}

The clearance of the weir with adopted assumptions was set on a flow of $77.7 \mathrm{~m}^{3} \cdot \mathrm{s}^{-1}$. Damming ordinate was set at $210.30 \mathrm{~m}$ a.s.l., and the crown's ordination was $211.60 \mathrm{~m}$ a.s.l. Weir was designed as a threshold with a wide crown and a step of $1.20 \mathrm{~m}$ height, with a $0.80 \mathrm{~m}$ deep outlet basin. The clearance 
of the weir was divided with a pillar into two slots, $5.70 \mathrm{~m}$ each. The maximum damming amounts to $2.22 \mathrm{~m}$. Two segments lifted with a manual drive are closing the clearance. The threshold under a valve and on a passage to an outlet basin was laid with a basalt cube. In the middle pillar, a ladder type stepped fish pass with a total length of $24.25 \mathrm{~m}$ was designed. The part running inside the pillar has a length of $6.85 \mathrm{~m}$, and the exposed part $-17.40 \mathrm{~m}$. The passage channel consists of 10 pools, as well as inlet and outlet pools. Inlet slots (assuming water flow direction) are located on both sides of the front end of the pillar with dimensions $0.55 \times 0.30 \mathrm{~m}$ submerged $0.80 \mathrm{~m}$ below water surface (from the bottom edge of a slot). Inlet channels, equipped with $0.15 \mathrm{~m}$ wide recesses that allow closing the entrance with valves, meet at an angle of $45^{0}$ with the $0.80 \mathrm{~m}$ wide main channel. The section running inside the pillar is divided by three bars forming two pools. Above the second pool (on the pillar) there is a grating of $1360 \times 860 \mathrm{~mm}$ letting sunlight through and allowing observation of water flow. Water flow rate in this part is $0.88 \mathrm{~m} \cdot \mathrm{s}^{-1}$.

The uncovered part of the fish pass includes 4 segments, with 2 pools per each segment. The outer wall is $0.20 \mathrm{~m}$ thick, internal walls (partitions) $-0.10 \mathrm{~m}$, with height $-0.25 \mathrm{~m}$, and slots $-0.25 \mathrm{~m}$ wide. Each pool of the fish pass is $2.0 \mathrm{~m}$ long, inlet pool has $1.25 \mathrm{~m}$ length and outlet pool $-1.40 \mathrm{~m}$. The bed width of the uncovered part of the fish pass is $1.0 \mathrm{~m}$, water flow rate $-0.77 \mathrm{~m} \cdot \mathrm{s}^{-1}$. Baffles are filled up to $0.52 \mathrm{~m}$. The outlet pool has three slots: from the front, on the right and on the left, with a possibility of closing each one with valves mounted in structural channels.

The framework of the fish pass cover is made of two angle irons $145 \times 45 \times 5 \mathrm{~mm}$, fastened to the inner edge of the walls, running on both sides along the entire length of the passage. Every 0.55 meters 21 pieces of cross-section angle $135 \times 35 \times 5 \mathrm{~mm}$ were welded onto them, whereas limit bars are flat bars $30 \times 6 \mathrm{~mm}$. A wire mesh of $\varnothing 6 \mathrm{~mm}$, with mesh size $40 \times 40 \mathrm{~mm}$ was stretched across it and welded under planes of two inwardly directed flat bars $45 \times 5 \mathrm{~mm}$ put onto framework angles. The covering is additionally reinforced with rods $\varnothing 16 \mathrm{~mm}$, laterally stretched by stirrups anchored in passage wall. There are two rods for each sector.

Figures from 3 to 7 show pictures of the tested

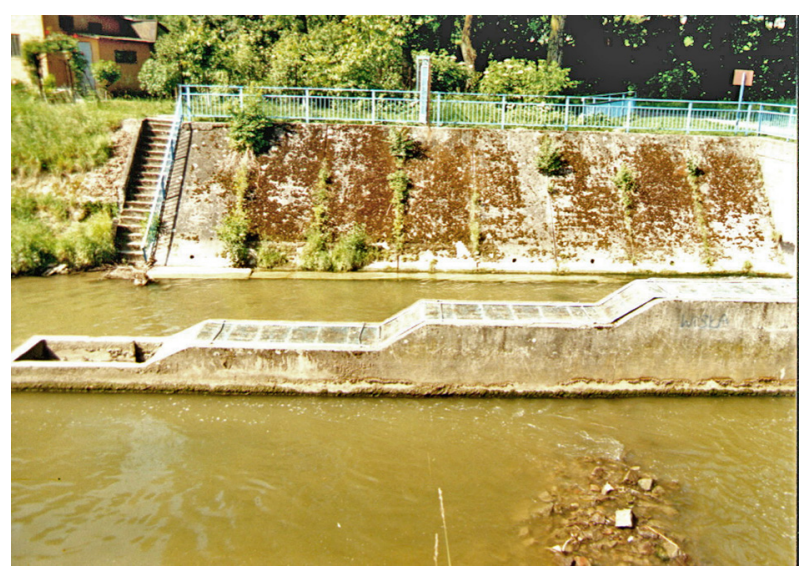

Fig. 3. Fish pass on Dłubnia River - longitudinal profile, side view (photo: A. Radecki-Pawlik)

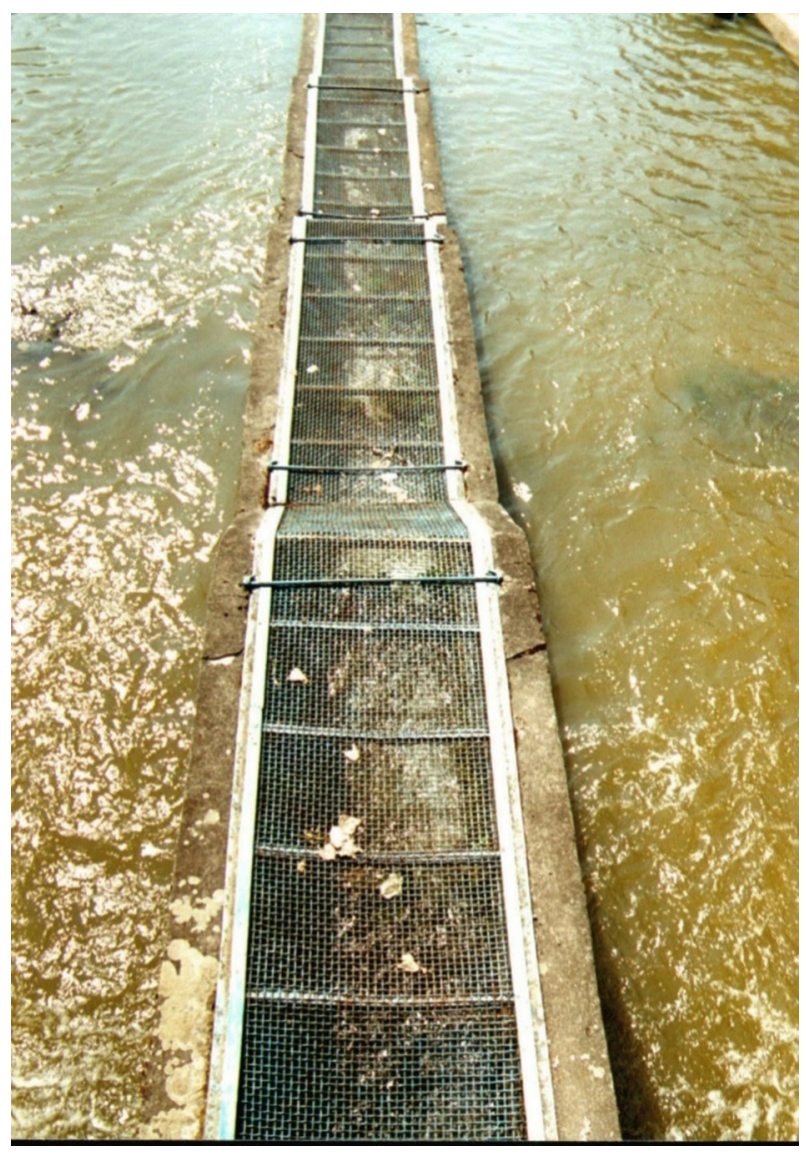

Fig. 4. Fish pass on Dłubnia River - top view (photo: A. Radecki-Pawlik) structure. 


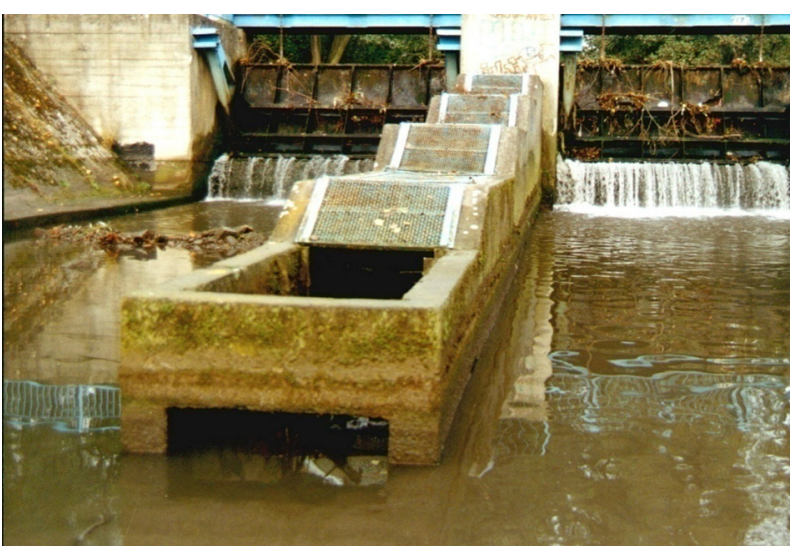

Fig. 5. Fish pass on Dłubnia River - view from downstream after draining the river channel (photo: G. Gajda)

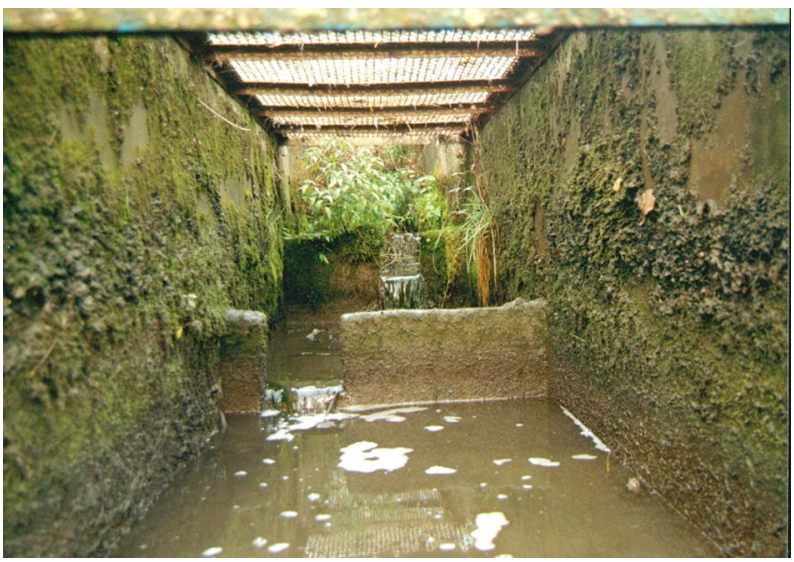

Fig. 6. Fish pass on Dłubnia River - inside view after draining the river channel (photo: G. Gajda)

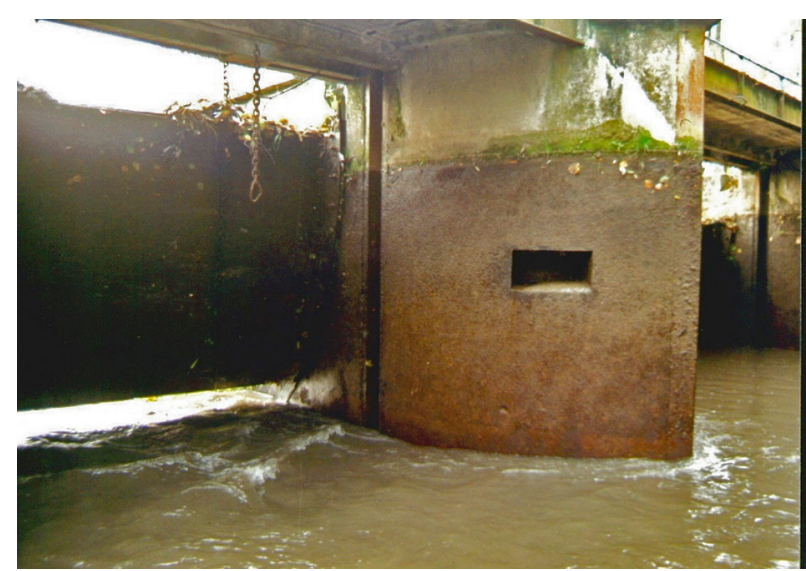

Fig 7. Fish pass on Dłubnia River - view of intake to fish pass through the river channel and the upstream reservoir (photo: G. Gajda)

\section{PROPOSED SOLUTION FOR IMPROVEMENT OF THE FISH PASS}

The existing fish pass located on the Dłubnia River is outdated, partly damaged and ineffective.

Inlets to the fish pass are too small. Inside the middle pillar fish have no access to sunlight along a $4 \mathrm{~m}$ section, which can affect them negatively. To ensure an adequate flow in a fish pass and an appropriate brightness of an upper part of a fish pass (located in a weir's pillar), each slot should be $100 \times 40 \mathrm{~cm}$. If inclination remains the same in a new double channel in the middle pillar of the weir, river boulders should be placed to dissipate water energy (see: Fig. 8a, c). Another way to dissipate energy includes rubber flanges, which should be attached to vertical walls at entire height in both channels (see: Fig. 8b). Both should be arranged alternately. In order to light up the channel, waterproof LED bulbs with a power of $14 \mathrm{~W}$ should be mounted onto the ceiling (see: Fig. 8a, b). These bulbs must operate continuously.

At the bottom outlet of the middle pillar of the weir, two existing channels should be separated by a $0.10 \mathrm{~m}$ high concrete barrier (see: Fig. 9). Two channels will be subsequently attached to the outer walls of the old fish pass with metal stilts, thus creating 3 pools with a length of $15 \mathrm{~m}$ (see: Fig. 9). The pools will be made of $0.10 \mathrm{~m}$ thick concrete. The first pool will have a depth of $1.50 \mathrm{~m}$, the second $-1.35 \mathrm{~m}$, and the third $-1.20 \mathrm{~m}$. The width of all pools will be the same $1.00 \mathrm{~m}$. A rectangular channel with a height of $1.05 \mathrm{~m}$, also made of $0.10 \mathrm{~m}$ thick concrete, will be attached to the last pool. This channel will also be connected to the existing fish pass. The pools will also be fixed into riverbed by stainless steel rods with a diameter of $10 \mathrm{~cm}$. New positioning of the pools reduces drop gradient, which facilitates the passage for fish. Rectangular channel will be about $10 \mathrm{~m}$ long with a pool located in the middle. The resting pool will be $1.00 \mathrm{~m}$ long, $0.45 \mathrm{~m}$ wide and $0.40 \mathrm{~m}$ high.

In the new system, there are two symmetrical channels for fish migration with the same dimensions as the existing fish pass (see: Fig. 10). All pools will have metal grids placed at the top of the system to avoid poaching. These gratings will be fixed into metal frames that will have hinges, which will allow them to be opened in case of required repair. 


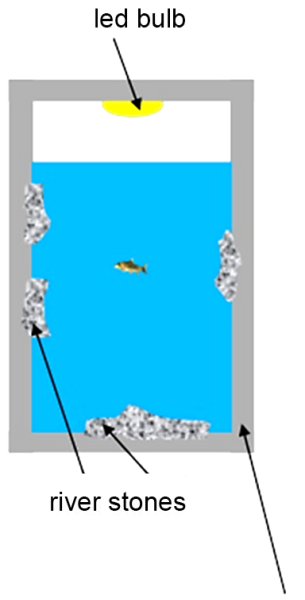

channel for fish migration located in the central pillar of the weir

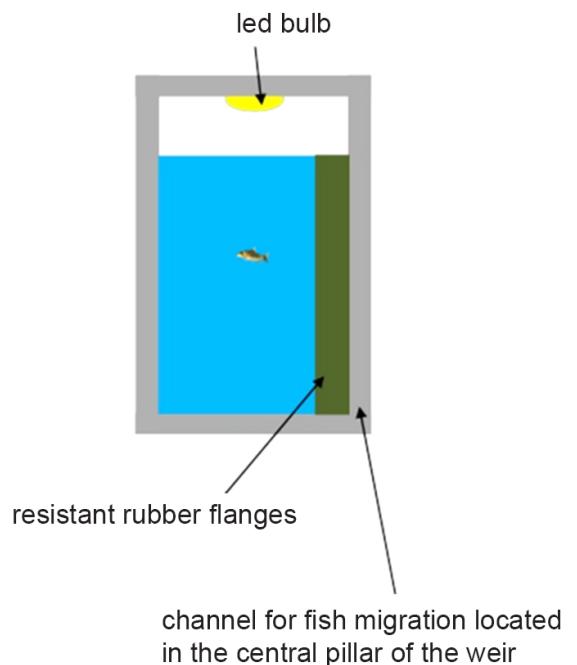

in the central pillar of the weir

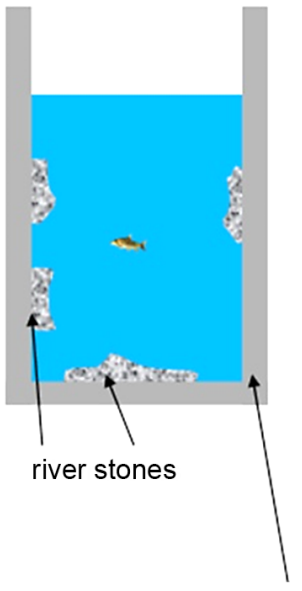

channel for fish migration located in the continuations of the basins

Fig. 8. Positioning of $(a, c)$ river stones, $(b)$ flanges and $(a, b)$ led bulbs inside the channels of fish pass

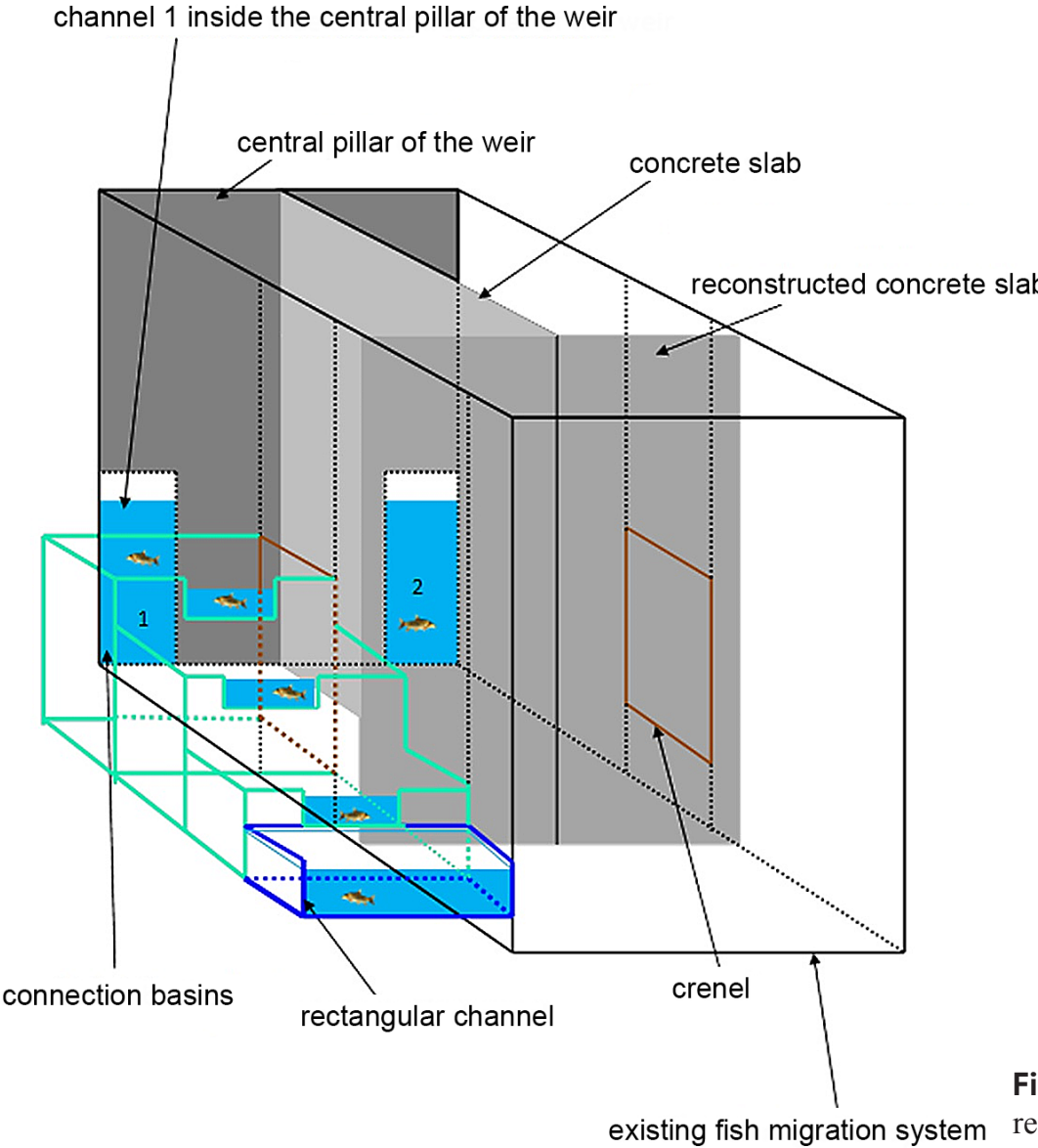

Fig. 9. Positioning of connection basins and existing fish migration system rectangular basin for fish migration 


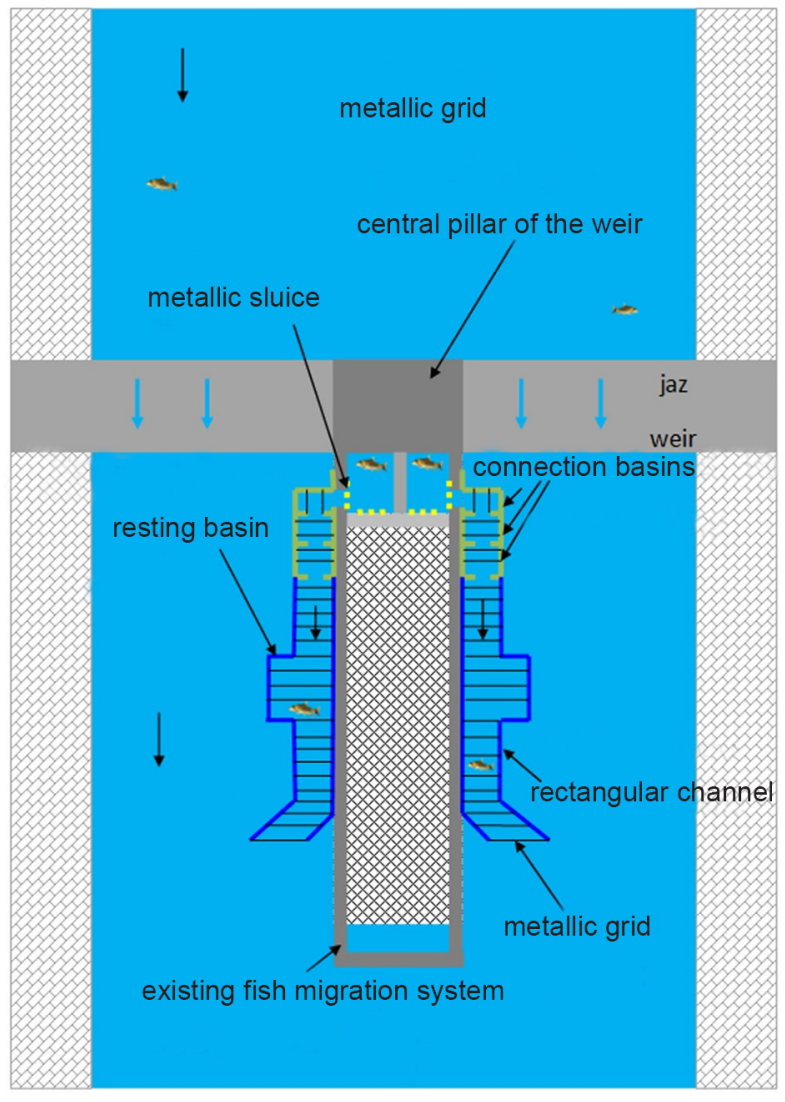

Fig. 10. Positioning of the two symmetrical fish migration systems

Two symmetrical systems with the same dimensions and properties, which are well set, do not support large damages during floods, can be relatively easily repaired, and due to design and materials used have a long preservation span.

\section{CONCLUSIONS}

Field vision of local fish pass with mobile weirs on the Dlubnia River in Cracow found that for many years the fish pass has not been functioning, because both inlet slots were closed by valves. This has happened at the beginning of the 1990s in a period of low waters caused by droughts, for which reason it was impossible to obtain normal levels of damming, and also by a "run off" of water through the fish pass $\left(0.40 \mathrm{~m}^{3} \cdot \mathrm{s}^{-1}\right)$.

Because no actions to restore functioning of the passage were taken, partitions were being choked and vegetation overgrew, which has found excellent conditions for development thanks to water flowing through leaky valves, covering walls, pools and partitions of the passage and reducing its clearance. At present stage it is flexible vegetation that has not led to any significant damage, however, allowing its development into rigid vegetation will cause further and much more serious detriment. It was also noticed that the outlet pool is completely blocked by anthropogenic contamination.

The proposed technical solutions enabling to clear the described fish pass should consist in implementation of a new fish migration system that will take over the role and tasks of the old fish pass. The new fish pass will include two independent and separate migration systems that fish can flow up the channel. In the upper part, both channels are introduced into the main pillar of the weir, where the new system connects with the old one. Lighting should be installed in pools in the pillar, because darkness and lack of access to natural light are inconvenient for fish migration. New fish pass is an innovative solution. The old system was unserviceable and raised a barrier for migrating fish, which is a weir on the Dlubnia River.

The paper discussed restoring a pool fish pass on the Dłubnia River in Cracow and putting it back into operation against the background of discussed measures for enabling fish migration in Poland and in Europe. The details of the technical solution of the facility and proposed specific improving actions were also shown. The paper is intended both for exploiters of this type of structures and for educational purposes of undertaking renovation and operation activities of hydrotechnical facilities. The research was carried out thanks to cooperation with Huta im Sendzimira in Krakow and its technical section.

\section{ACKNOWLEDGEMENTS}

The research was carried out in cooperation with Tadeusz Sendzimir Steelworks.

\section{REFERENCES}

Bartnik, W., Epler, P., Jelonek, M., Klaczak, A., Książek, L., Mikołajczyk, T., Nowak, M., Popek, W., Sławińska, A., Sobieszczyk, P., Szczerbik, P., Wyrębek, M. (2011). 
Gospodarka rybacka w aspekcie udrażniania cieków dorzecza Małej i Górnej Wisły. Infrastruktura i Ekologia Terenów Wiejskich, PAN - Oddział w Krakowie, Komisja Technicznej Infrastruktury Wsi, Kraków, 230.

Bartnik, W., Książek, L., Jelonek, M., Sobieszczyk, P., Florek, J., Hawryło, A., Leja, M., Strużyński, A., Strutyński, M., Wałęga, A., Wyrębek, W., Wiśniewolski, W., Parasiewicz, P., Prus, P., Adamczyk, M., Depowski, R., (2015). Warunki przywracania struktury siedlisk dla ryb na odcinku rzeki Wisłoka w km 73+200 $\div 42+600$, Gospodarka Wodna, 5, 147-152.

Bartnik, W., Książek, L., Wyrębek, M. (2010). Hydrauliczne warunki występowania prądu wabiącego dla przepławek ryglowych. Infrastruktura i Ekologia Terenów Wiejskich, 9, 123-132.

Bojarski, A., Jeleński, J., Jelonek, M., Litewka, T., Wyżga, B., Zalewski, J. (2005). Zasady dobrej praktyki w utrzymaniu rzek i potoków górskich. Warszawa: Ministerstwo Środowiska, Departament Zasobów Wodnych, 143

BSiPH (1995). Jaz na rzece Dłubnia w Krakowie. Dokumentacja techniczna, Kraków: BSiPH.

DWA 2014. DWA-Merkblatt M 509. Fish Ladders and Fish Passable Structures [Fischaufstiegsanlagen und fischpassierbare Bauwerke] (in German)

Dyrektywa 2000/60/WE Parlamentu Europejskiego i Rady z dnia 23 października 2000r. ustanawiająca ramy wspólnotowego działania w dziedzinie polityki wodnej.

Gebler R. J. (1991). The natural design of structures and fish ladders for establishing connections with flowing waters [Naturgemäße Bauweisen von Sohlenbauwerken und Fischaufstiegen zur Vernetzung der Fließgewässer]. Mitteilungen des Institutes für Wasserbau und Kulturtechnik, pp. 181 (in German)

Jarocki, W. (1966). Budownictwo wodne. Warszawa: PWSZ. Jens, G. (1982). Der Bau von Fishwagen. Verlag Paul Parey : Hamburg, Berlin.

Kałuża, T., Hammerling, M. (2015). Problemy projektowania i eksploatacji przepławek dla ryb. Poznań: Bogucki.

Michalec, B. (2013). Ocena warunków hydraulicznych w przepławce szczelinowej jazu głównego zbiornika wodnego w Zesławicach na rzece Dłubni. Acta Scientiarum Polonorum, Formatio Circumiectus, 12(1), 91100.

Mokwa, M., Tyminski, T. (2018). Hydraulic Calculations for Fish Passes. In: A. Radecki-Pawlik, S. Pagliara, J. Hradecky Open Channel Hydraulics, River Hydraulic Structures and Fluvial Geomorphology. For Engineers, Geomorphologists and Physical Geographers, CRC Press.
Plesiński, K., Radecki-Pawlik, A. (2018). Bystrza o zwiększonej szorstkości. Rodzaje, przykłady z praktyki, hydraulika, projektowanie i problemy eksploatacyjne. Kraków: Wydawnictwo UR.

Radecki-Pawlik, A., Plesiński, K. Pałyga, M. (2015). W sprawie przepławek dla ryb - przykłady z praktyki. In: T. Kałuża, M. Hammerling. Problemy projektowania i eksploatacji przepławek dla ryb. Poznań: Bogucki.

Radecki-Pawlik A., Plesiński K., Radecki-Pawlik B. 2017 Rozkład prędkości oraz naprężeń stycznych w komorach przepławki typu wielkokomorowego. Acta Scientiarum Polonorum, Formatium Circumiectus, 16(1), 149-159.

Rozporządzenie Ministra Ochrony Środowiska Zasobów Naturalnych i Leśnictwa z 20.12.1996 r., paragraf 22.

Skatula, L. (1964). Zabudowa rzek i potoków górskich. Warszawa: PWRiL.

Witkowska, M., Płowens, T., Humiczewski, M. (2013a). Budowa niebieskiego korytarza ekologicznego wzdłuż doliny rzeki Regi i jej dopływów. Gospodarka Wodna, 10, 403-405.

Tymiński, T., Mumot, J., Strojny, R., Karpowicz, D. (2016). Analysis of the potential of building ramps in hydrotechnical structures as a means of facilitating fish migratory. Acta Scientiarum Polonorum, Formatium Circumiectus, 15(3), 151-162.

Voicu, R., Baki, P. (2017). Improving upstream and downstream fish passage at Retis Dam on Hartibaciu river Sibiu county (Transylvania), Annals of Valahia University of Targoviste. Geographical Series, 17(1), 47-57.

Voicu, R., Bretcan, P. (2014). Solution for fish migration on the Somesul Mic river upstream-downstream of Manastur Dam in Cluj Napoca, Annals of Valahia University of Targoviste. Geographical Series, 14(2), 125-132.

Voicu, R., Costescu, C., Voicu, L., Lengher-Bica, N. (2015). Solution for ichthyofauna migration upstream-downstream of the two spillways located near Manastur Dam on the Somesul Mic river in the Cluj Napoca city (Romania), Lakes, reservoirs and ponds, 9(1), 43-55.

Voicu, R., Dominguez, L.G. (2016). Facilitation fish migration above the discharge sill located on the Ialomita river near cave Ialomicioara. Annals of Valahia University of Targoviste. Geographical Series, 16(2), 44-58.

Voicu, R., Miles, K.N. (2016). Principle and design of hatch operation system for fish migrating upstream-downstream of the discharge sill. Acta Scientiarum Polonorum, Formatium Circumiectus, 15(3), 163-176.

Witkowska, M., Płowens, T., Humiczewski, M. (2013b). Budowa niebieskiego korytarza ekologicznego wzdłuż doliny rzeki Regi i jej dopływów, część II. Gospodarka Wodna, 11, 444-445. 
Wyrębek, M. (2013). Przepławki ryglowe jako element przywrócenia ciągłości korytarza ekologicznego rzek silnie zmienionych. Infrastruktura i Ekologia Terenów Wiejskich, 3/I, 61-71.

WWF (2016). Przepławki dla ryb. Projektowanie, wymiary i monitoring [Fish passes. Design, dimensions dna monitoring]. DVWK, FAO
Zubek, S. (1998). Wydarzenie głośne i niegłośne. Kropla Magazyn Ekologiczny, 3, 21.

https://biala-tarnowska.org/ - Strona internetowa projektu „Przywrócenie ciągłości ekologicznej i realizacja działań poprawiających funkcjonowanie korytarza swobodnej migracji rzeki Białej Tarnowskiej”

\section{PROBLEM ISTNIEJĄCYCH PRZEPŁAWEK DLA RYB I KWESTII ICH REMONTU - ZE SZCZEGÓLNYM UWZGLĘDNIENIEM PRZEPŁAWKI KOMOROWEJ NA RZECE DŁUBNI W KRAKOWIE}

\section{ABSTRACT}

\section{Cel pracy}

Celem pracy jest określenie pracy przepławki komorowej znajdującej się na rzece Dłubni oraz próba określenia zaleceń naprawczych, dzięki którym będzie działać prawidłowo i nie będzie stanowić przeszkody dla migrujących ryb.

\section{Materiał i metody}

Wizja terenowa. Określenie elementów przepławki mogących limitować przepływ ryb w oparciu o normy, które podają typowe wymiary geomteryczne. Próba określenia jej naprawy.

\section{Wyniki i wnioski}

Przepławka nie działa prawidłowo. W pracy przedstawiono zalecenia naprawcze.

Słowa kluczowe: przepławka dla ryb, jaz, remont, drożność przepławki 